\title{
Transplantation of betacellulin-transduced islets improves glucose intolerance in diabetic mice
}

\author{
Mi-Young Song ${ }^{1}$, Ui-Jin Bae ${ }^{1}$, Kyu Yun Jang ${ }^{2}$ and Byung-Hyun Park ${ }^{1,3}$
}

Type 1 diabetes is an autoimmune disease caused by permanent destruction of insulin-producing pancreatic $\beta$ cells and requires lifelong exogenous insulin therapy. Recently, islet transplantation has been developed, and although there have been significant advances, this approach is not widely used clinically due to the poor survival rate of the engrafted islets. We hypothesized that improving survival of engrafted islets through ex vivo genetic engineering could be a novel strategy for successful islet transplantation. We transduced islets with adenoviruses expressing betacellulin, an epidermal growth factor receptor ligand, which promotes $\beta$-cell growth and differentiation, and transplanted these islets under the renal capsule of streptozotocin-induced diabetic mice. Transplantation with betacellulin-transduced islets resulted in prolonged normoglycemia and improved glucose tolerance compared with those of control virus-transduced islets. In addition, increased microvascular density was evident in the implanted islets, concomitant with increased endothelial von Willebrand factor immunoreactivity. Finally, cultured islets transduced with betacellulin displayed increased proliferation, reduced apoptosis and enhanced glucosestimulated insulin secretion in the presence of cytokines. These experiments suggest that transplantation with betacellulintransduced islets extends islet survival and preserves functional islet mass, leading to a therapeutic benefit in type 1 diabetes. Experimental \& Molecular Medicine (2014) 46, e98; doi:10.1038/emm.2014.24; published online 30 May 2014

Keywords: angiogenesis; betacellulin; gene therapy; islets transplantation

\section{INTRODUCTION}

Transplantation of the pancreas or isolated islets is presently the only curative therapy for type 1 diabetes. Compared with whole pancreas transplantation, islet transplantation is a much less invasive procedure and is associated with lower morbidity. ${ }^{1}$ However, international trials have demonstrated a constant decline of graft function and a relatively low rate of successful engraftment compared with pancreas transplantation. ${ }^{2}$ This relatively high rate of transplant failure has been attributed to the mode of blood supply reestablishment. Similar to other solid organ transplantations, the transplanted pancreas is implanted as a vascularized tissue and can receive immediate blood supply via physical reconnection of blood vessels. In contrast, transplanted islets become avascular after collagenase digestion and microvascular perfusion to newly implanted islets does not resume immediately after transplantation. ${ }^{3}$ As a result, newly implanted islets are deprived of oxygen and nutrients for several days, resulting in inflammation and apoptosis. In addition, the relatively harsh islet isolation procedure and immune-mediated injury of islets after transplantation limit successful islet transplantation. ${ }^{4,5}$ Therefore, strategies using genetic overexpression of proteins involved in promoting new blood vessel formation or inhibiting apoptosis may improve the transplantation outcome. ${ }^{6}$

Betacellulin is a member of the epidermal growth factor family and signals through the epidermal growth factor receptor. ${ }^{7}$ Like other epidermal growth factor receptor ligands, betacellulin is initially produced as a transmembrane protein that is cleaved by specific proteases to release the circulating form. ${ }^{8}$ Betacellulin is expressed in pancreatic $\alpha$ cells, $\beta$ cells and duct cells. ${ }^{9}$ Betacellulin stimulates the proliferation of pancreatic cancer cell lines, ${ }^{10}$ inhibits apoptosis, ${ }^{11}$ promotes the neogenesis of $\beta$ cells ${ }^{12}$ and converts non- $\beta$ cells into insulin-producing cells. ${ }^{13}$ These in vitro studies suggest that betacellulin has an important role in differentiation, growth and survival of pancreatic $\beta$ cells. Several animal studies have also shown the therapeutic potential of betacellulin in the treatment of type 1 diabetes. Injection

\footnotetext{
${ }^{1}$ Department of Biochemistry, Chonbuk National University Medical School, Jeonbuk, Republic of Korea; ${ }^{2}$ Department of Pathology, Chonbuk National University Medical School, Jeonbuk, Republic of Korea and ${ }^{3}$ Research Institute for Endocrine Sciences, Chonbuk National University Medical School, Jeonbuk, Republic of Korea

Correspondence: Professor B-H Park, Department of Biochemistry, Chonbuk National University Medical School, 567 Baekje-daero, Deokjin-gu, Jeonju, Jeonbuk 561-756, Republic of Korea.

E-mail: bhpark@jbnu.ac.kr

Received 3 September 2013; revised 14 January 2014; accepted 23 January 2014
} 
of recombinant betacellulin or adenovirus expressing betacellulin promotes $\beta$-cell regeneration and ameliorates glucose intolerance in both streptozotocin (STZ)-induced diabetic mice m-16 $^{14}$ and $90 \%$ pancreatectomized diabetic rats. ${ }^{17}$ Transplantation of mesenchymal stem cells transduced with betacellulin significantly reduced glucose levels of STZ-treated rats. $^{18}$ In addition, there is evidence that betacellulin exerts potent angiogenic activity through activation of mitogen-activated protein kinase and phosphatidylinositide 3-kinase. ${ }^{19}$

On the basis of the dual function of betacellulin in neogenesis of $\beta$ cells and angiogenesis, we hypothesized that overexpression of betacellulin in transplanted islets would enhance revascularization and thus protects islets from hypoxic injury. To address this issue, we used a gene therapy approach involving adenovirus-mediated betacellulin gene delivery into pancreatic islets. Results show that transplantation with betacellulin-transduced islets is associated with significantly improved islet engraftment and functional islet mass, which correlate with adequate glycemic control in diabetic mice.

\section{MATERIALS AND METHODS}

\section{Cell culture and reagents}

Rat pancreatic $\beta$-cell RINm5F cells were acquired from the American Type Culture Collection (Manassas, VA, USA) and were grown at $37^{\circ} \mathrm{C}$ in a humidified $5 \% \mathrm{CO}_{2}$ atmosphere in RPMI 1640 medium (Gibco BRL, Grand Island, NY, USA) supplemented with 10\% fetal bovine serum and $2 \mathrm{mmoll}^{-1}$ glutamine, 100 units $\mathrm{ml}^{-1}$ penicillin, $100 \mu \mathrm{g} \mathrm{ml}^{-1}$ streptomycin and $2.5 \mu \mathrm{g} \mathrm{ml}^{-1}$ amphotericin B. Recombinant human betacellulin was purchased from Sigma-Aldrich (St Louis, MO, USA). Interleukin- $1 \beta$ and interferon $-\gamma$ were obtained from R\&D Systems (Minneapolis, MN, USA). All reagents were from Sigma-Aldrich unless otherwise noted.

\section{MTT assay for cell viability}

The viability of RINm5F cells was determined using the reduction of 3-(4, 5-dimethylthiazol-2-yl)-2, 5-diphenyltetrazolium bromide (MTT) to formazan. ${ }^{20}$

\section{Nitric oxide (NO) measurement}

Biologically produced NO is rapidly oxidized to nitrite and nitrate in aqueous solutions. NO production was measured as nitrite concentration in cell-free culture supernatants using a colorimetric assay. $^{21}$

\footnotetext{
Western blot analysis

Cells or islets were homogenized in $100 \mu$ ice-cold lysis buffer $(20 \mathrm{~mm}$ HEPES pH 7.2, 1\% Triton X-100, 10\% glycerol, 1 mm phenylmethylsulfonyl fluoride, $10 \mu \mathrm{g} \mathrm{ml}^{-1}$ leupeptin and $10 \mu \mathrm{g} \mathrm{ml}^{-1}$ aprotinin) and $20 \mu \mathrm{g}$ of protein were separated using sodium dodecyl sulfatepolyacrylamide gel electrophoresis and transferred to nitrocellulose membranes. The blots were probed with $1 \mu \mathrm{g} \mathrm{ml}^{-1}$ primary antibodies for Bcl-2, inducible nitric oxide synthase, Akt, and $\beta$-actin (all from Santa Cruz Biotechnology, Santa Cruz, CA, USA), Bax and p-Akt (Cell Signaling, Beverly, MA, USA), and betacellulin (R\&D Systems). Horseradish peroxidase-conjugated immunoglobulin G (Zymed, South San Francisco, CA, USA) was used as a secondary antibody.
}

\section{Animals and materials}

Specific pathogen-free male C57BL/6 mice, weighing 25-30g, were purchased from Orient Bio (Seoul, Korea) and used as both donors and recipients. Mice were housed in a laminar flow cabinet with a 12-h light-dark cycle and maintained on standard laboratory chow ad libitum. All the animal experiments were performed in accordance with the Guide for the Care and Use of Laboratory Animals published by the US National Institutes of Health (NIH publication no. 85-23, revised 2011). This study protocol was approved by the Institutional Animal Care and Use Committee of Chonbuk National University.

\section{Preparation of the recombinant adenovirus}

The adenovirus containing the betacellulin (Ad-BTC) was kindly donated by HS Jun (Gachon University of Medicine and Science, Incheon, Korea). ${ }^{16}$ Recombinant replication-defective adenovirus containing $\beta$-galactosidase (Ad-LacZ) was used as a control. HEK293 cells were used for virus amplification. Viruses from the culture supernatants of HEK 293A cells that showed cytopathogenic effects were purified by cesium chloride banding. Virus titers were determined by plaque assay using serial dilution. Adenoviral transduction of the islets was performed using a multiplicity of infection of 100 per islet.

\section{Islet isolation and determination of islet viability}

Pancreatic islets were isolated from male C57BL/6 mice using the collagenase digestion method. Islet viability was evaluated as previously described. ${ }^{21}$ Briefly, islets were incubated with cytokines and fixed overnight in a solution of $6.5 \%$ glutaraldehyde. Islet viability was determined by hematoxylin-eosin staining and labeling for antiinsulin antibody (Santa Cruz Biotechnology). Apoptosis was detected by the ApoPercentage Apoptosis Assay Kit (Biocolor, Newtownabbey, Ireland). This assay relies on the ApoPercentage dye that is selectively imported by apoptotic cells. ${ }^{22}$ Apoptotic cells developed red color following the intake of ApoPercentage dye and were detected under an inverted light microscope.

\section{5-Bromo-2-deoxyuridine (BrdU)-labeling cell proliferation assay}

A cell proliferation enzyme-linked immunosorbent assay (BrdU kit; Amersham Biosciences, Piscataway, NJ, USA) was used to measure the incorporation of BrdU during DNA synthesis. Briefly, islets were transduced with either Ad-BTC or Ad-LacZ and then treated with interleukin-1 $\beta\left(1 \mathrm{U} \mathrm{ml}^{-1}\right)$ and interferon- $\gamma\left(100 \mathrm{U} \mathrm{ml}^{-1}\right)$. After a 48 $\mathrm{h}$ incubation, $\operatorname{BrdU}(10 \mu \mathrm{M})$ was added to the culture medium for $12 \mathrm{~h}$, the BrdU-labeled cells were fixed and the DNA was denatured in fixative solution for $30 \mathrm{~min}$ at room temperature. Islets were incubated with peroxidase-conjugated anti-BrdU antibody for $2 \mathrm{~h}$ at room temperature and washed three times with washing solution. Immune complexes were detected by the $3,3^{\prime}, 5,5^{\prime}$-tetramethylbenzidine substrate reaction and absorbance measured at $405 \mathrm{~nm}$ with a Spectra Max Plus spectrophotometer (Molecular Devices, Sunnyvale, CA, USA).

\section{Glucose-stimulated insulin secretion (GSIS) assay}

Transduced islets with either Ad-BTC or Ad-LacZ were cultured for $24 \mathrm{~h}$ with interleukin-1 $\beta\left(1 \mathrm{U} \mathrm{ml}^{-1}\right)$ and interferon- $\gamma\left(100 \mathrm{Uml}^{-1}\right)$ and subsequently washed three times in Krebs-Ringer bicarbonate buffer ( $25 \mathrm{~mm}$ HEPES, $115 \mathrm{mmoll}^{-1} \mathrm{NaCl}, 24 \mathrm{mmoll}^{-1} \mathrm{NaHCO}_{3}$, $5 \mathrm{mmoll}^{-1} \mathrm{KCl}, 1 \mathrm{mmoll}^{-1} \mathrm{MgCl}_{2}, 2.5 \mathrm{mmoll}^{-1} \mathrm{CaCl}_{2}, 0.1 \%$ bovine serum albumin, $\mathrm{pH} 7.4$ ) containing $2.8 \mathrm{mmoll}^{-1} \mathrm{D}$-glucose. Insulin 
secretion assays were performed with 2.8 or $16.7 \mathrm{mmoll}^{-1}$ D-glucose and measured using an enzyme-linked immunosorbent assay kit (Millipore, Bedford, MA, USA).

\section{Islet transplantation and glucose tolerance test}

To induce diabetes, mice were injected via tail vein with $80 \mathrm{mg} \mathrm{kg}^{-1}$ body weight STZ dissolved in $0.1 \mathrm{moll}^{-1}$ sodium citrate buffer $(\mathrm{pH}$ 4.0 ), prepared within $5 \mathrm{~min}$ of administration. Mice were considered diabetic when their blood glucose levels were over $300 \mathrm{mg} \mathrm{dl}^{-1}$ for 2 consecutive days. One week after STZ treatment, diabetic mice were randomly divided into three groups. A marginal islet mass (100 islets) that was untreated or transduced with either Ad-BTC or Ad-LacZ was transplanted beneath the left renal capsule of syngeneic recipient mice. The day on which islets were transplanted was defined as day 1 . After transplantation, blood was sampled from the tail vein for glucose measurement. To test the function of engrafted islets, a glucose tolerance test was performed at 35 days after transplantation. Overnight-fasted mice were injected with $2 \mathrm{~g} \mathrm{~kg}^{-1}$ body weight of glucose solution followed by tail vein blood sampling at $0,30,60,120$ and $180 \mathrm{~min}$ after injection. At 63 days after transplantation, a left nephrectomy was performed in the transplanted mice to confirm a return to hyperglycemia. Blood glucose levels were measured by Accu-Chek Aviva glucose monitors (Roche Diagnostics, Indianapolis, IN, USA).

\section{Histological assessment}

Mice were killed under nonfasting conditions 65 days after transplantation. The graft-bearing kidney and pancreatic specimens were immediately fixed in $10 \%$ formalin solution, embedded in paraffin and cut into $5 \mu \mathrm{m}$ sections. Specimens were stained with hematoxylineosin to identify morphological changes. For immunohistochemical study, tissue sections were treated using a microwave antigen retrieval procedure in $0.01 \mathrm{moll}^{-1}$ sodium citrate buffer. After blocking endogenous peroxidase, the sections were incubated with Protein Block Serum-Free (DAKO, Carpinteria, CA, USA) to block nonspecific staining, then with anti-insulin antibody (Santa Cruz Biotechnology), anti-betacellulin antibody (R\&D Systems), or anti-von Willebrand factor (vWF) antibody (Bio-Rad, Raleigh, NC, USA). Peroxidase activity was detected with 3-amino-9-ethyl carbazole.

\section{Statistical analysis}

Statistical analyses were performed using analysis of variance and Duncan's tests. Differences with a $P<0.05$ were considered statistically significant.

\section{RESULTS}

\section{Effects of betacellulin on cytokine-mediated cell death in} isolated islets

To investigate the effect of betacellulin on cytokine toxicity, we transduced mouse islets with Ad-BTC or Ad-LacZ. We first determined whether betacellulin overexpression in islets protects against cytokine toxicity. Islets were exposed to interleukin- $1 \beta$ and interferon- $\gamma$ for $48 \mathrm{~h}$, and the extent of apoptosis was compared (Figure 1a). There was almost 12 times more apoptosis observed in cytokine-treated islets than in vehicle treated islets $(80.0 \pm 5.0 \%$ vs $6.6 \pm 4.4 \%$, $P<0.01)$. However, there were significantly fewer apoptotic islets in betacellulin-transduced samples $(36.6 \pm 7.2, P<0.01)$ than in cytokine-treated islets. In the presence of betacellulin antibody, Ad-BTC did not protect islets against cytokine toxicity, suggesting betacellulin-specific apoptosis inhibition. Similarly, when islets were exposed to tumor necrosis factor- $\alpha$, betacellulin also had a protective effect against tumor necrosis factor- $\alpha$ treatment (Supplementary Figure S1).

The expression levels of apoptosis-related proteins were examined by western blotting (Figure 1b). Compared with control islets, expression of the proapoptotic protein Bax was increased and expression of the antiapoptotic protein $\mathrm{Bcl}-2$ was decreased in cytokine-treated islets. These patterns were not observed in betacellulin-transduced islets. In parallel, we examined $\beta$-cell proliferation by measuring BrdU incorporation. Betacellulin transduction increased cell proliferation by approximately twofold compared with cytokine-treated islets, whereas control virus-transduced islets remained quiescent (Figure 1c). In addition, recombinant human betacellulin increased Akt phosphorylation as early as $1 \mathrm{~min}$ and produced a maximal effect at $5 \mathrm{~min}$ (Figure 1d).

Islets were further stained with hematoxylin-eosin or immunostained with anti-insulin antibody to confirm apoptosis. As expected, treatment with cytokines resulted in islet damage with weak insulin immunoreactivity (Figures $2 \mathrm{~A} \mathrm{~b}, \mathrm{f}$ ). However, betacellulin-transduced islets blocked the effect of the cytokines and had similar morphology to control islets in both hematoxylin-eosin and immunohistochemical stainings: well-defined margins and round shape, and strong insulin immunoreactivity in the $\beta$ cells of the islets (Figures $2 \mathrm{~A} \mathrm{~d}, \mathrm{~h}$ ).

To provide functional data, the effect of betacellulin against cytokine-induced impairment of insulin secretion was evaluated (Figure 2B). We assayed basal and GSIS after cytokine exposure. The results showed that the amount of GSIS was $30.47 \pm 3.8 \mathrm{ng}$ per $\mathrm{mg}$ protein per hour in control islets and $6.29 \pm 0.6 \mathrm{ng}$ per $\mathrm{mg}$ protein per hour in cytokine-treated islets $(P<0.01)$. However, following transduction with betacellulin, the degree of cytokine-impaired insulin secretion was restored to a level close to that of the control. Basal insulin release among the groups was similar.

When RINm5F insulinoma cells were used, betacellulin was also effective at protecting the cells from cytokine toxicity. Treatment with cytokines significantly reduced the cell viability to $35.8 \pm 18.5 \%$ of that of the control (Supplementary Figure S2A). In addition, inducible nitric oxide synthase expression and NO production were significantly increased by cytokine treatment (Supplementary Figure S2B). Consistent with the islet data, transduction of RINm5F cells with betacellulin almost completely blocked cytokine-induced inducible nitric oxide synthase expression, NO production and cytotoxicity.

\section{Effects of betacellulin on glycemic control}

Our in vitro results show that betacellulin has a $\beta$-cell protective effect against cytokines and increases islet viability. To examine whether this $\beta$-cell protection improves islet engraftment and glycemic control, we transduced a marginal islet mass (100 islets) with Ad-BTC or Ad-LacZ and transplanted under the left renal capsule of STZ-induced diabetic mice. As shown in Figure 3, diabetic mice transplanted with 
a

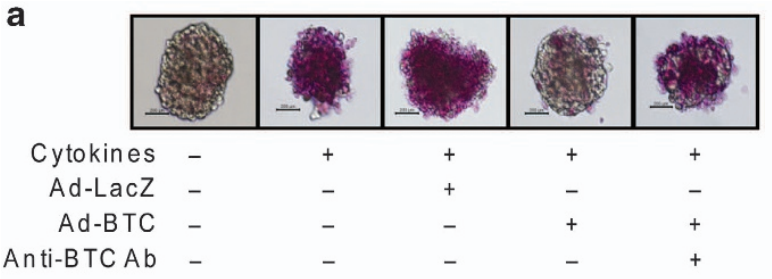

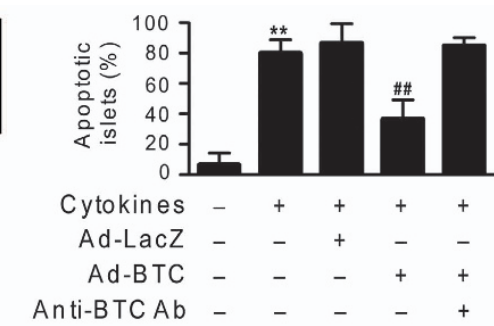

C

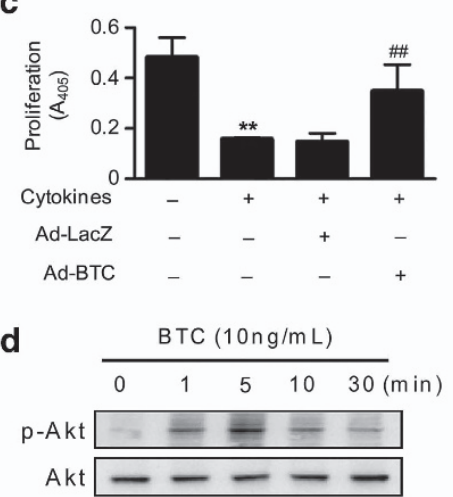

Figure 1 Betacellulin prevents cytokine-induced apoptosis in isolated islets. (a) Mouse islets were transduced with adenoviruses expressing betacellulin (Ad-BTC) or $\beta$-galactosidase (Ad-LacZ), and then treated with interleukin (IL)-1 $\beta$ ( $1 \mathrm{Uml} \mathrm{ml}^{-1}$ ) and interferon- $\gamma$ $\left(100 \mathrm{U} \mathrm{ml}^{-1}\right)$ in the presence or absence of anti-BTC antibody $\left(500 \mathrm{ng} \mathrm{ml}^{-1}\right)$. Following a 48 -h incubation, the extent of apoptosis was determined by the amount of ApoPercentage dye accumulated in islets. (b) Islet extracts were prepared $24 \mathrm{~h}$ after cytokine treatment and the expression levels of apoptosis-related proteins were examined by western blot. Relative intensity showed the ratio of the expression compared with that of $\beta$-actin. (c) After $48 \mathrm{~h}$ of cytokine treatment, $\beta$-cell proliferation was measured by 5-bromo-2-deoxyuridine (BrdU) incorporation in islets transduced with either Ad-BTC or Ad-LacZ. (d) Islets were treated with recombinant human betacellulin $\left(10 \mathrm{ng} \mathrm{m}^{-1}\right)$ until the indicated time points and subjected to western blot analysis with anti-p-Akt or anti-Akt antibody. Each value represents the mean \pm s.e.m. $(n=9)$. ${ }^{*} P<0.01$ vs untreated control; ${ }^{\# \#} P<0.01$ vs Ad-LacZ.

A

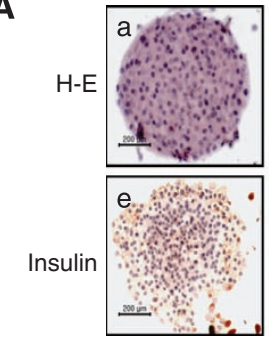

Cytokines

Ad-LacZ

Ad-BTC b
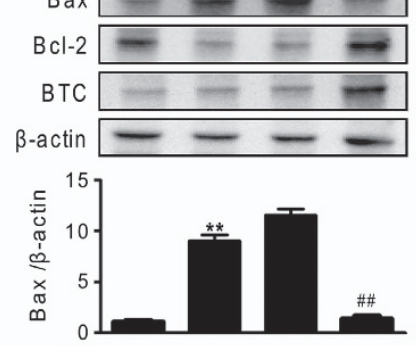

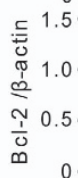

Cytokines

Ad-LacZ
57

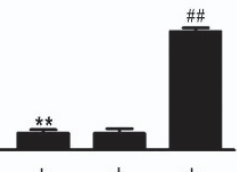


betacellulin-transduced islets (Ad-BTC mice) had significantly reduced blood glucose levels at almost all-time points. In contrast, diabetic mice transplanted with the same number of islets that were transduced with Ad-LacZ (Ad-LacZ mice) remained hyperglycemic. No significant differences in the degree of hyperglycemia were observed between Ad-LacZ and untransplanted phosphate-buffered saline mice at the endpoint. To confirm islet graft function, nephrectomy was performed to remove graft-bearing kidneys in diabetic recipient mice 63 days post-transplantation. Nephrectomy resulted in the recurrence of severe hyperglycemia in the Ad-BTC mice.

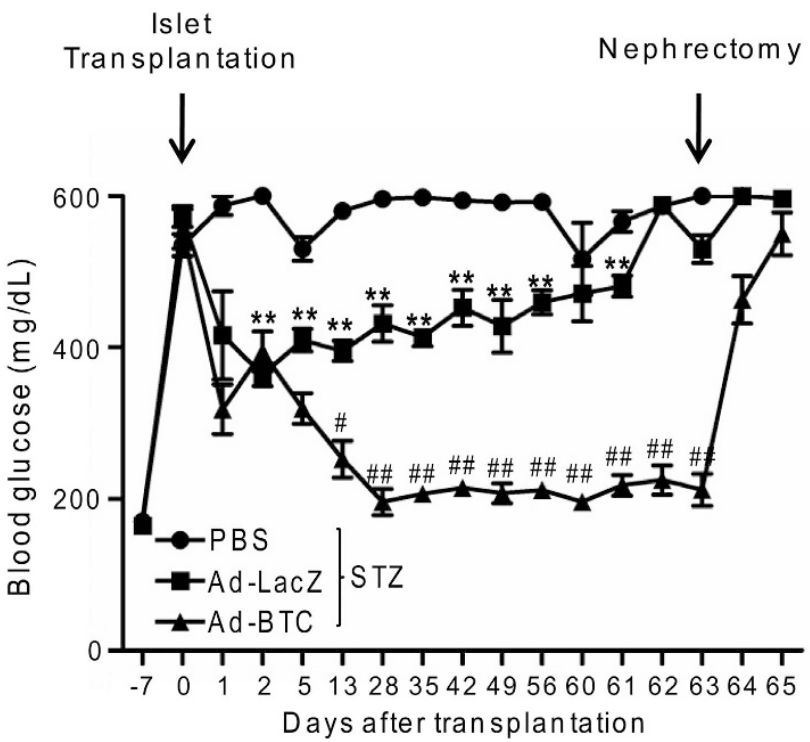

Figure 3 Betacellulin transduction improves islet engraftment. Blood glucose levels were monitored in streptozotocin (STZ)-induced diabetic mice transplanted with betacellulin or $\beta$-galactosidasetransduced islets for 65 days. Each value represents the mean \pm s.e.m. $(n=9)$. ${ }^{*} P<0.01$ vs STZ; ${ }^{\#} P<0.05$, ${ }^{\# \#} P<0.01$ vs adenoviruses expressing $\beta$-galactosidase (Ad-LacZ).
These results indicate that betacellulin improves the performance of transplanted islets in glycemic control in diabetic mice.

To study the effect of betacellulin on GSIS from transplanted islets, we performed glucose tolerance tests on diabetic mice 35 days post-transplantation, followed by the determination of blood glucose profiles and plasma insulin levels. As shown in Figure 4a, Ad-BTC mice had significantly improved blood glucose profiles. These results were corroborated by the quantification of the area under the curve of blood glucose profiles during glucose tolerance tests. As expected from their improved blood glucose profiles, plasma insulin levels were significantly higher in the Ad-BTC mice compared with Ad-LacZ mice at 35 days post-transplantation (Figure $4 \mathrm{~b}$ ).

To rule out the possibility that this improved glycemic control in the Ad-BTC mice is due to neogenesis of insulinproducing $\beta$ cells in the pancreas, we immunostained pancreatic tissues of recipient mice with anti-insulin antibody. As shown in Supplementary Figure S3, there were no distinguishable differences in insulin immunoreactive $\beta$ cells among groups. These results indicate that the metabolic improvement in Ad-BTC mice is due to the presence of donor islets in the kidney.

\section{Effects of betacellulin on islet revascularization}

Next, to study the effects of betacellulin on islet engraftment, mice were killed 35 days post-transplantation. Islet grafts were retrieved and subjected to immunohistochemistry using antibodies against insulin to identify functional islets, and antibody against vWF to visualized newly formed blood vessels. As shown in Figure 5a, insulin immunoreactivity was stronger in engrafted islets in Ad-BTC mice than in Ad-LacZ mice. In addition, islet grafts in Ad-BTC mice exhibited more vWFpositive vessels than those in Ad-LacZ mice (Figure 5b). This difference in vascular density between Ad-BTC and Ad-LacZ mice correlated with their differences in blood glucose profiles and plasma insulin levels (Figure 4). a

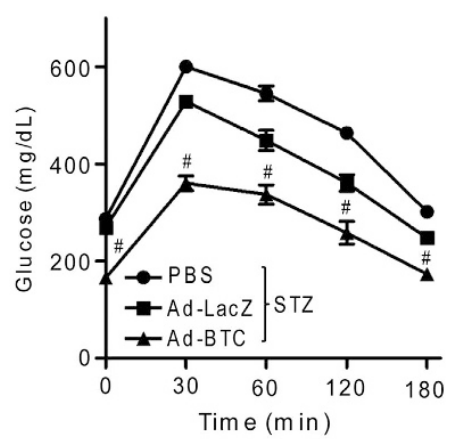

STZ

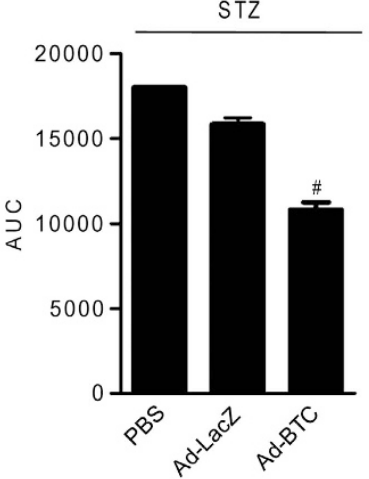

b

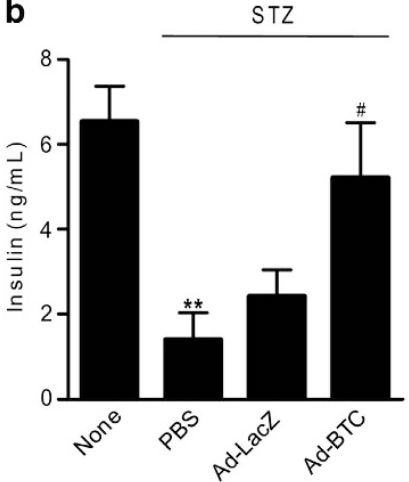

Figure 4 Betacellulin increases glucose-stimulated insulin secretion from transplanted islets. Thirty-five days after transplantation, diabetic mice were fasted overnight and injected intraperitoneally with $2 \mathrm{~g} \mathrm{~kg}^{-1}$ glucose solution. (a) Blood glucose profiles and the corresponding area under the curve (AUC) values were measured during the glucose tolerance test. (b) Plasma insulin levels were determined under basal conditions. Each value represents the mean \pm s.e.m. $(n=9-12)$. ${ }^{* *} P<0.01$ vs untreated control; ${ }^{\#} P<0.05$ vs adenoviruses expressing $\beta$-galactosidase (Ad-LacZ). 


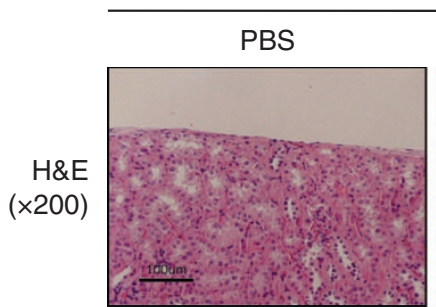

\section{STZ}
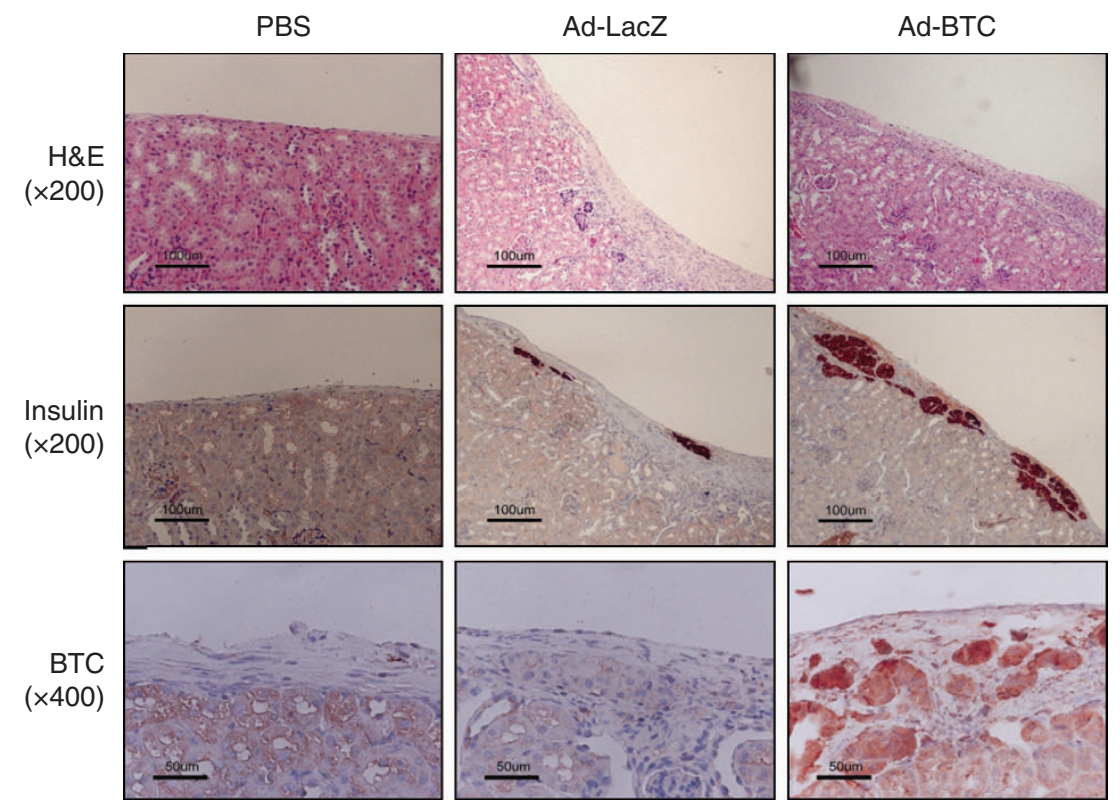

b

STZ

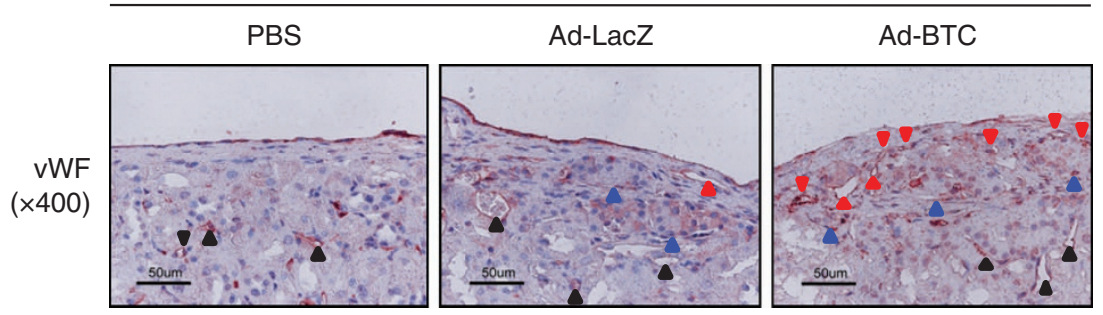

Figure 5 Betacellulin increases new blood vessel formation in transplanted islets. Fourteen (for betacellulin (BTC) staining) or 35 (for hematoxylin-eosin (H\&E), insulin, and von Willebrand factor (VWF) staining) days after transplantation, diabetic mice were terminated and islet grafts were retrieved. (a) Paraffin-embedded islet grafts were sectioned and stained with H\&E or immunostained with anti-insulin or anti-BTC antibody. (b) Paraffin-embedded islet grafts were immunostained with anti-vWF antibody. The black arrowheads indicate internalpositive blood vessels, the red arrowheads indicate newly formed blood vessels and the blue arrowheads indicate transplanted islets. Photomicrographs are representative of three independent experiments.

\section{DISCUSSION}

As diabetes results from absolute or relative deficiency in $\beta$-cell mass, islet transplantation is a potential strategy for the treatment of diabetes. Various methods have been investigated to improve graft survival including transduction of islets with angiogenic growth factor. This study was undertaken to evaluate the potential effect of betacellulin, an angiogenic, antiapoptotic and $\beta$-cell growth factor, on the extent of islet engraftment and glycemic control in diabetic mice. To this end, we looked at cytokine-induced pancreatic $\beta$-cell damage in transplanted syngeneic islets. The results show enhanced islet revascularization in diabetic mice transplanted with betacellulin-transduced islets. In addition, cultured islets or insulinoma cells that were transduced with betacellulin were subsequently more resistant to cytokine toxicity and had decreased the numbers of apoptotic $\beta$ cells. These events led to enhanced islet engraftment, improved glycemic control and elevated serum insulin.
The betacellulin-mediated increase in angiogenesis in transplanted islets is a remarkable feature that has not been reported previously. Kim et al. ${ }^{19}$ initially demonstrated that betacellulin has angiogenic effects. Using human umbilical vein endothelial cells, the authors found that betacellulin promoted vessel formation and cell survival through activation of mitogen-activated protein kinase and phosphatidylinositide 3-kinase/Akt pathways. In addition, betacellulin itself has been implicated in angiogenesis in hepatocellular carcinoma ${ }^{23}$ and wound healing. ${ }^{24}$ These reports indicate that betacellulin is a strong angiogenic growth factor and can be used for enhancing revascularization of transplanted islets.

We therefore investigated whether betacellulin enhanced islet revascularization. To answer this question, we transplanted a marginal mass of betacellulin-transduced islets under the renal capsule of diabetic mice. We found that this procedure had a beneficial effect in increasing islet vascular density at 5 weeks after transplantation. This increase further 
led to increases in insulin-positive $\beta$ cells and vWFpositive endothelial cells, indicating that the intragraft vascular structures are functionally active and adequate vascularization increases survival of engrafted islets. Indeed, a positive relationship between angiogenesis and improved graft survival is well documented in the literature. For example, adenovirus-mediated vascular endothelial growth factor ${ }^{25}$ or angiopoietin- $1^{26}$ overexpression in islets resulted in augmented islet engraftment and improved glycemic control in diabetic mice. In contrast, blocking angiogenesis with C-statin impeded islet engraftment. ${ }^{27}$ Taken together, the results of this study and those of other studies indicate that transduction of islets with angiogenic growth factor is an effective way to accelerate islet engraftment after transplantation.

One explanation for the increased survival of engrafted islets, besides improved vascularization, may be direct effects of betacellulin on rates of apoptosis and proliferation in the pancreatic islets. We estimated the apoptosis rate in cultured islets after cytokine treatment and found that the apoptosis rate in cytokine-treated islets was significantly suppressed by betacellulin transduction. The role of betacellulin in $\beta$-cell proliferation was highlighted again in this study. Consistent with the putative proliferative role of betacellulin, ${ }^{12,13}$ adenoviral-mediated overexpression of betacellulin in islets resulted in a significant increase in proliferation, whereas overexpression of $\beta$-galactosidase had no effect. An earlier study by Buteau et al. ${ }^{28}$ demonstrated that the proliferative effect of betacellulin is mediated by phosphatidylinositide 3-kinase. Consistent with this report, we observed an increased level of pAkt in betacellulin-treated islets suggesting that phosphatidylinositide 3-kinase activation in these islets lead to $\beta$-cell proliferation. All together, these findings indicate that betacellulin improves the long-term outcome of islet transplantation by increasing revascularization, $\beta$-cell proliferation and resistance to apoptosis.

Diabetic mice transplanted with betacellulin-transduced islets became normoglycemic for a longer time than mice transplanted with $\beta$-galactosidase-transduced islets. Although we did not measure circulating betacellulin levels, we believe that improved glycemic control is due to the autocrine or paracrine action of locally produced betacellulin from transplanted islets in the kidney. In summary, this study extends previous reports that rapid reestablishment of a functional microvasculature in transplanted islets is crucial for islet survival and transplantation outcomes. Therefore, betacellulin can be used for ex vivo gene therapy to preserve islet mass and to improve the success rate of islet transplantation.

\section{ACKNOWLEDGEMENTS}

This work was supported by the Bio and Medical Technology Development Program (no. NRF-2012M3A9B2027975); the Basic Science Research Program (no. 2013012280); the Medical Research Center Program (no. 2008-0062279); and the research fund of Chonbuk National University in 2013 (to M-YS).
1 Ricordi C, Strom TB. Clinical islet transplantation: advances and immunological challenges. Nat Rev Immunol 2004; 4: 259-268.

2 Shapiro AM, Ricordi C, Hering BJ, Auchincloss H, Lindblad R, Robertson RP et al. International trial of the Edmonton protocol for islet transplantation. New Engl J Med 2006; 355: 1318-1330.

3 Jansson L, Carlsson PO. Graft vascular function after transplantation of pancreatic islets. Diabetologia 2002; 45: 749-763.

4 Warnock GL, Meloche RM, Thompson D, Shapiro RJ, Fung M, Ao Z et al. Improved human pancreatic islet isolation for a prospective cohort study of islet transplantation vs best medical therapy in type 1 diabetes mellitus. Arch Surg 2005; 140: 735-744.

5 Westwell-Roper C, Dai DL, Soukhatcheva G, Potter KJ, van Rooijen N, Ehses JA et al. IL-1 blockade attenuates islet amyloid polypeptide-induced proinflammatory cytokine release and pancreatic islet graft dysfunction. $J$ Immunol 2011; 187: 2755-2765.

6 Wang X, Meloche M, Verchere CB, Ou D, Mui A, Warnock GL. Improving islet engraftment by gene therapy. J Transplant 2011; 2011: 594851.

7 Shing Y, Christofori G, Hanahan D, Ono Y, Sasada R, Igarashi $\mathrm{K}$ et al. Betacellulin: a mitogen from pancreatic beta cell tumors. Science 1993; 259: 1604-1607.

8 Sahin U, Weskamp G, Kelly K, Zhou HM, Higashiyama S, Peschon J et al. Distinct roles for ADAM10 and ADAM17 in ectodomain shedding of six EGFR ligands. J Cell Biol 2004; 164: 769-779.

9 Miyagawa J, Hanafusa O, Sasada R, Yamamoto K, Igarashi K, Yamamori K et al. Immunohistochemical localization of betacellulin, a new member of the EGF family, in normal human pancreas and islet tumor cells. Endocr $J$ 1999; 46: 755-764.

10 Kawaguchi M, Hosotani R, Kogire M, Ida J, Doi R, Koshiba T et al. Autoinduction and growth stimulatory effect of betacellulin in human pancreatic cancer cells. Int J Oncol 2000; 16: 37-41.

11 Saito T, Okada S, Ohshima K, Yamada E, Sato M, Uehara $Y$ et al. Differential activation of epidermal growth factor (EGF) receptor downstream signaling pathways by betacellulin and EGF. Endocrinology 2004; 145: 4232-4433

12 Kojima H, Fujimiya M, Matsumura K, Younan P, Imaeda H, Maeda M et al. NeuroD-betacellulin gene therapy induces islet neogenesis in the liver and reverses diabetes in mice. Nat Med 2003; 9: 596-603.

13 Nagaoka T, Fukuda T, Hashizume T, Nishiyama T, Tada H, Yamada H et al. A betacellulin mutant promotes differentiation of pancreatic acinar AR42 J cells into insulin-producing cells with low affinity of binding to ErbB1. J Mol Biol 2008; 380: 83-94.

14 Chen S, Ding J, Yu C, Yang B, Wood DR, Grayburn PA. Reversal of streptozotocin-induced diabetes in rats by gene therapy with betacellulin and pancreatic duodenal homeobox-1. Gene Ther 2007; 14: 1102-1110.

$15 \mathrm{Li} \mathrm{L}$, Yi Z, Seno M, Kojima I. Activin A and betacellulin: effect on regeneration of pancreatic $\beta$-cells in neonatal streptozotocin-treated rats. Diabetes 2004; 53: 608-615.

16 Shin S, Li N, Kobayashi N, Yoon JW, Jun HS. Remission of diabetes by $\beta$-cell regeneration in diabetic mice treated with a recombinant adenovirus expressing betacellulin. Mol Ther 2008; 16: 854-861.

17 Li L, Seno M, Yamada H, Kojima I. Promotion of $\beta$-cell regeneration by betacellulin in ninety percent-pancreatectomized rats. Endocrinology 2001; 142: 5379-5385.

18 Paz AH, Salton GD, Ayala-Lugo A, Gomes C, Terraciano P, Scalco R et al. Betacellulin overexpression in mesenchymal stem cells induces insulin secretion in vitro and ameliorates streptozotocin-induced hyperglycemia in rats. Stem Cells Dev 2011; 20: 223-232.

19 Kim HS, Shin HS, Kwak HJ, Cho CH, Lee CO, Koh GY. Betacellulin induces angiogenesis through activation of mitogen-activated protein kinase and phosphatidylinositol 3'-kinase in endothelial cell. FASEB $J$ 2003: 17: 318-320.

20 Bae UJ, Song MY, Jang HY, Gim HJ, Ryu JH, Lee SM et al. The efficacy of SPA0355 in protecting $\beta$ cells in isolated pancreatic islets and in a murine experimental model of type 1 diabetes. Exp Mol Med 2013; 45: e51.

21 Lv N, Kim EK, Song MY, Choi HN, Moon WS, Park SJ et al. JANEX-1, a JAK3 inhibitor, protects pancreatic islets from cytokine toxicity through downregulation of NF-KB activation and the JAK/STAT pathway. Exp Cell Res 2009; 315: 2064-2071.

22 Lee HS, Woo SJ, Koh HW, Ka SO, Zhou L, Jang KY et al. Regulation of apoptosis and inflammatory responses by IGFBP-3 in fibroblastlike synoviocytes and experimental animal models of rheumatoid arthritis. Arthritis Rheum 2014; 66: 863-873. 
23 Moon WS, Park HS, Yu KH, Park MY, Kim KR, Jang KY et al. Expression of betacellulin and epidermal growth factor receptor in hepatocellular carcinoma: implications for angiogenesis. Hum Pathol 2006; 37: 1324-1332.

24 Schneider MR, Antsiferova M, Feldmeyer L, Dahlhoff M, Bugnon P, Hasse $S$ et al. Betacellulin regulates hair follicle development and hair cycle induction and enhances angiogenesis in wounded skin. J Invest Dermatol 2008; 128: 1256-1265.

25 Zhang N, Richter A, Suriawinata J, Harbaran S, Altomonte J, Cong $\mathrm{L}$ et al. Elevated vascular endothelial growth factor production in islets improves islet graft vascularization. Diabetes 2004; 53: 963-970.

26 Su D, Zhang N, He J, Qu S, Slusher S, Bottino R et al. Angiopoietin-1 production in islets improves islet engraftment and protects islets from cytokine-induced apoptosis. Diabetes 2007; 56: 2274-2283.
27 Zhang N, Qu S, Xu J, Bromberg JS, Dong HH. Inhibition of angiogenesis is associated with reduced islet engraftment in diabetic recipient mice. Transplant Proc 2005; 37: 4452-4457.

28 Buteau J, Foisy S, Joly E, Prentki M. Glucagon-like peptide 1 induces pancreatic beta-cell proliferation via transactivation of the epidermal growth factor receptor. Diabetes 2003; 52: 124-132.

\section{(c) (1) $(\Theta)$ This work is licensed under a Creative Commons Attribution-NonCommercial-NoDerivs 3.0 Un- ported License. To view a copy of this license, visit http:// creativecommons.org/licenses/by-nc-nd/3.0/}

Supplementary Information accompanies the paper on Experimental \& Molecular Medicine website (http://www.nature.com/emm) 